\title{
Palladium complexes of a new type of $\mathbf{N}$-heterocyclic carbene ligand derived from a tricyclic triazolooxazine framework
}

\author{
MANOJ KUMAR GANGWAR, ALOK CH KALITA and PRASENJIT GHOSH* \\ Department of Chemistry, Indian Institute of Technology Bombay, Powai, Mumbai 400 076, India \\ e-mail:pghosh@chem.iitb.ac.in
}

MS received 9 April 2014; revised 22 April 2014; accepted 14 May 2014

\begin{abstract}
A new type of tricyclic triazolooxazine derived N-heterocyclic carbene precursors were developed by the alkylation reaction of a tricyclic triazolooxazine framework. In particular, the reaction of 5a,6,7,8,9,9ahexahydro-4 $H$-benzo[ $[b][1,2,3]$ triazolo[1,5- $d][1,4]$ oxazine with methyl iodide and ethyl iodide yielded the tricyclic triazolooxazine derived N-heterocyclic carbene precursors, $(\mathbf{1 - 2}) \mathbf{a}$, in $67-84 \%$ yield. The tricyclic triazolooxazinium iodide salts, $(\mathbf{1}-\mathbf{2}) \mathbf{a}$, underwent metallation in a straight forward manner upon treatment with $\mathrm{PdCl}_{2}$ in the presence of $\mathrm{K}_{2} \mathrm{CO}_{3}$ in pyridine to give the trans- $\{3-(\mathrm{R})-5 \mathrm{a}, 6,7,8,9,9 \mathrm{a}$-hexahydro- $4 \mathrm{H}$ benzo[b][1,2,3]triazolo[1,5- $d][1,4]$ oxazin-4-ylidene $\} \operatorname{PdI}_{2}$ (pyridine) $[\mathrm{R}=\mathrm{Me}(\mathbf{1 b})$, Et $(\mathbf{2 b})]$ complexes in $23-25 \%$ yield. The new tricyclic triazolooxazine derived N-heterocyclic carbene moiety, as stabilized upon binding to palladium in the $(\mathbf{1}-\mathbf{2}) \mathbf{b}$ complexes, was structurally characterized by the X-ray single crystal diffraction studies.
\end{abstract}

Keywords. Palladium; tricyclic triazolooxazine derived N-heterocyclic carbene (NHC); PEPPSI.

\section{Introduction}

The unprecedented success of the imidazole-based Nheterocyclic carbenes as wonder ligands in homogeneous catalysis has generated immense interest in other variants of these stable singlet carbene ligands ${ }^{1}$ as part of a larger effort on gauging their true potential in the area. $^{2}$ Consequently, large number of structural motifs of varying types have been developed of these carbene ligands that extend much beyond the more conventional imidazole based saturated and unsaturated five-membered carbenes to pyrazole derived carbenes, six-, seven-, and eight-membered NHCs, acyclic diaminocarbenes (ADCs), abnormal mesoionic NNCs, to name a few. All these carbene ligands showcase some very elegant and innovative work in the dual realms of synthesis and homogeneous catalysis. These developments have largely advanced the fields of asymmetric catalysis, ${ }^{11}$ various types of polymerization ${ }^{12}$ reactions, organocatalysis, ${ }^{13}$ and the countless methodology development reactions of relevance to the organic synthesis ${ }^{14}$ extending all the way to total synthesis. ${ }^{15}$

One of our longstanding objective remains to identify and understand the key attributes of the N-heterocyclic carbenes responsible for their phenomenal success in homogeneous catalysis. ${ }^{16}$ In this regard, we have looked into various types of $\mathrm{N}$-heterocyclic carbene ligand

*For correspondence frameworks of the 5 -membered imidazole ${ }^{17}$ and the triazole $^{18}$ rings, a 6 -membered ${ }^{19}$ saturated cyclic ring and the imidazo[1,2- $a$ ]pyridine ${ }^{20}$ scaffolds for a host of different transformations like, the $\mathrm{C}-\mathrm{C}$ cross-coupling reaction, the base-free Michael addition reaction, the $\mathrm{C}-\mathrm{N}$ bond forming alkene and alkyne hydroamination reactions and the ring-opening polymerization of the L-lactides. Proceeding further along the line, we set out to look into the other new motifs of the N-heterocyclic carbene ligands. In particular, we became interested in the $\mathrm{N}$-fused tricyclic ring derived carbene ligands having chiral centres with restricted rotation as these are expected to significantly facilitate more asymmetric induction during the catalysis over the analogous carbene ligands having freerotation of their chiral ancillary. To start with, we decided to synthesize the racemic versions of these tricyclic triazolooxazine derived $\mathrm{N}$-heterocyclic carbene ligands with the intent of overcoming the synthetic challenge and for establishing the preparative protocol before taking up the synthesis of their asymmetric counterparts.

Herein, we report a new tricyclic triazolooxazine derived $\mathrm{N}$-heterocyclic carbene ligand stabilized in its (NHC) $\mathrm{PdI}_{2}$ (pyridine) type palladium complexes, and the structural characterization of which provide valuable insights into the binding preference of this new ligand. 


\section{Experimental}

\subsection{General procedures}

All manipulations were carried out using standard Schlenk techniques. Solvents were purified and degassed by standard procedures. Cyclohexene oxide and propargyl bromide were purchased from Sigma Aldrich Chemicals and used without any further purification. ${ }^{1} \mathrm{H}$ and ${ }^{13} \mathrm{C}\left\{{ }^{1} \mathrm{H}\right\}$ NMR spectra were recorded on a Bruker $500 \mathrm{MHz}$ NMR spectrometer. ${ }^{1} \mathrm{H}$ NMR peaks are labeled as singlet (s), doublet (d), triplet (t), quartet (q), doublet of triplets (dt), triplet of triplets (tt), multiplet (m). The 5a,6,7,8,9,9a-hexahydro-4Hbenzo[b][1,2,3]triazolo[1,5- $d][1,4]$ oxazine $^{21}$ was synthesized by modification of a procedure reported in literature. Infrared spectra were recorded on a Perkin Elmer Spectrum One FT-IR spectrometer. Mass spectrometry measurements were done on a Micromass Q-Tof spectrometer. Elemental Analysis was carried out on Thermo Quest FLASH 1112 SERIES (CHNS) Elemental Analyzer. X-ray diffraction data were collected on a Rigaku $\mathrm{Hg} 724+$ diffractometer.

\subsection{Synthesis of 3-methyl-5a,6,7,8,9,9a-hexahydro- 4H-benzo[b][1,2,3]triazolo[1,5-d][1,4]oxazinium iodide (1a)}

A mixture of $5 \mathrm{a}, 6,7,8,9,9 \mathrm{a}$-hexahydro- $4 H$-benzo $[b][1$, $2,3]$ triazolo[1,5- $d][1,4]$ oxazine $(4.67 \mathrm{~g}, 26.0 \mathrm{mmol})$ and methyl iodide $(18.5 \mathrm{~g}, 131 \mathrm{mmol})$ was refluxed overnight in acetonitrile ( $c a .100 \mathrm{~mL}$ ), after which, the solvent was removed under vacuum. The yellow solid thus obtained was further purified by column chromatography using silica gel as a stationary phase and eluted with methanol/chloroform ( $v / v$ 1:9) to give the product as a light yellow solid 1a (6.99 g, 84\%). ${ }^{1} \mathrm{H} \mathrm{NMR}\left(\mathrm{CDCl}_{3}, 500 \mathrm{MHz}, 25^{\circ} \mathrm{C}\right): \delta 9.24$ (s, $1 \mathrm{H}, \mathrm{C}_{2} \underline{H} \mathrm{~N}_{3}$ of $\left.\mathrm{C}_{9} \mathrm{H}_{13} \mathrm{~N}_{3} \mathrm{O}\right), 5.33\left(\mathrm{~d}, 1 \mathrm{H},{ }^{2} J_{\mathrm{HH}}=16\right.$ $\mathrm{Hz}, \mathrm{OCH}_{2}$ of $\left.\mathrm{C}_{9} \underline{H}_{13} \mathrm{~N}_{3} \mathrm{O}\right), 5.22\left(\mathrm{~d}, 1 \mathrm{H},{ }^{2} J_{\mathrm{HH}}=16 \mathrm{~Hz}\right.$, $\mathrm{OCH}_{2}$ of $\mathrm{C}_{9} \underline{H}_{13} \mathrm{~N}_{3} \mathrm{O}$ ), 4.51 (s, $\left.3 \mathrm{H}, \mathrm{CH}_{3}\right), 4.26-4.21$ (m, $1 \mathrm{H}, \mathrm{C}_{6} \underline{H}_{10}$ of $\left.\mathrm{C}_{9} \mathrm{H}_{13} \mathrm{~N}_{3} \mathrm{O}\right), 3.98-3.93\left(\mathrm{~m}, 1 \mathrm{H}, \mathrm{C}_{6} \underline{H}_{10}\right.$ of $\mathrm{C}_{9} \mathrm{H}_{13} \mathrm{~N}_{3} \mathrm{O}$ ), 2.79-2.76 (m, $1 \mathrm{H}, \mathrm{C}_{6} \underline{H}_{10}$ of $\mathrm{C}_{9} \mathrm{H}_{13} \mathrm{~N}_{3} \mathrm{O}$ ), 2.22-2.20 (m, $1 \mathrm{H}, \mathrm{C}_{6} \underline{H}_{10}$ of $\left.\mathrm{C}_{9} \mathrm{H}_{13} \mathrm{~N}_{3} \mathrm{O}\right), 1.99-1.84$ (m, $3 \mathrm{H}, \mathrm{C}_{6} \underline{H}_{10}$ of $\left.\mathrm{C}_{9} \mathrm{H}_{13} \mathrm{~N}_{3} \mathrm{O}\right), 1.61-1.48\left(\mathrm{~m}, 3 \mathrm{H}, \mathrm{C}_{6} \underline{H}_{10}\right.$ of $\left.\mathrm{C}_{9} \mathrm{H}_{13} \mathrm{~N}_{3} \mathrm{O}\right) .{ }^{13} \mathrm{C}\left\{{ }^{1} \mathrm{H}\right\}$ NMR $\left(\mathrm{CDCl}_{3}, 125 \mathrm{MHz}\right.$, $\left.25^{\circ} \mathrm{C}\right): \delta 137.1\left(\underline{C}_{2} \mathrm{HN}_{3}\right.$ of $\left.\mathrm{C}_{9} \mathrm{H}_{13} \mathrm{~N}_{3} \mathrm{O}\right), 128.0\left(\underline{C}_{2} \mathrm{HN}_{3}\right.$ of $\left.\mathrm{C}_{9} \mathrm{H}_{13} \mathrm{~N}_{3} \mathrm{O}\right), 77.0\left(\underline{C}_{6} \mathrm{H}_{10}\right.$ of $\left.\mathrm{C}_{9} \mathrm{H}_{13} \mathrm{~N}_{3} \mathrm{O}\right), 63.4\left(\underline{C}_{6} \mathrm{H}_{10}\right.$ of $\left.\mathrm{C}_{9} \mathrm{H}_{13} \mathrm{~N}_{3} \mathrm{O}\right), 61.6\left(\mathrm{O}_{\underline{C}} \mathrm{H}_{2}\right.$ of $\left.\mathrm{C}_{9} \mathrm{H}_{13} \mathrm{~N}_{3} \mathrm{O}\right), 41.2\left(\underline{\mathrm{C}} \mathrm{H}_{3}\right)$, $29.8\left(\underline{C}_{6} \mathrm{H}_{10}\right.$ of $\left.\mathrm{C}_{9} \mathrm{H}_{13} \mathrm{~N}_{3} \mathrm{O}\right), 27.0\left(\underline{C}_{6} \mathrm{H}_{10}\right.$ of $\left.\mathrm{C}_{9} \mathrm{H}_{13} \overline{\mathrm{N}}_{3} \mathrm{O}\right)$, $23.2\left(\underline{C}_{6} \mathrm{H}_{10}\right.$ of $\left.\mathrm{C}_{9} \mathrm{H}_{13} \mathrm{~N}_{3} \mathrm{O}\right), 23.0\left(\underline{C}_{6} \mathrm{H}_{10}\right.$ of $\left.\mathrm{C}_{9} \mathrm{H}_{13} \mathrm{~N}_{3} \mathrm{O}\right)$. IR data $\left(\mathrm{cm}^{-1}\right) \mathrm{KBr}$ pellet: 3108 (w), 2997 (w), 2955 (m), 2943 (m), 2897 (w), 2868 (w), 1577 (w), 1447 (m), 1436 (m), 1378 (w), 1336 (m), 1299 (w), 1276 (w), 1172 (m), 1093 (s), 1087 (s), 1059 (m), 1027 (m), 950 (w), 942 (w), 847 (w), 829 (m), 806 (m), 755 (w), 626 (w). HRMS (ES): $m / z$ 194.1288, (M) ${ }^{+}$, Calcd. 194.1288. Anal. Calcd. for $\mathrm{C}_{10} \mathrm{H}_{16} \mathrm{IN}_{3} \mathrm{O}$ : C, 37.40; H, 5.02; N, 13.08. Found: C, 37.20; H, 4.63; N, 13.07 .

\subsection{Synthesis of trans3-methyl-5a,6,7,8,9,9a- hexahydro-4H-benzo[b][1,2,3]triazolo[1,5-d][1,4] oxazin-4-ylidene\} $\mathrm{PdI}_{2}$ (pyridine) (1b)}

A mixture of 3-methyl-5a,6,7,8,9,9a-hexahydro-4Hbenzo[b][1,2,3]triazolo[1,5- $d][1,4]$ oxazinium iodide (0.588 g, $1.82 \mathrm{mmol}), \mathrm{PdCl}_{2}(0.325 \mathrm{~g}, 1.82 \mathrm{mmol})$, $\mathrm{K}_{2} \mathrm{CO}_{3}(2.02 \mathrm{~g}, 14.7 \mathrm{mmol})$ and $\mathrm{NaI}(1.37 \mathrm{~g}, 9.14$ $\mathrm{mmol}$ ) was refluxed in pyridine ( $\mathrm{ca} .7 \mathrm{~mL}$ ) for 16 hours. The reaction mixture was then cooled to room temperature, diluted with $\mathrm{CHCl}_{3}$ (ca. $200 \mathrm{~mL}$ ) and subsequently washed with saturated aqueous $\mathrm{CuSO}_{4}$ solution $(c a .3 \times 50 \mathrm{~mL})$. The organic layer was separated and dried over anhydrous $\mathrm{Na}_{2} \mathrm{SO}_{4}$ and filtered. The filtrate was concentrated under vacuum to give a sticky, brown residue. The residue thus obtained was further purified by column chromatography using silica gel as a stationary phase and eluted with methanol/chloroform $(v / v 1: 9)$ mixture to give the product as a yellow solid $1 \mathbf{b}(0.295 \mathrm{~g}, 25 \%)$. The product was crystallized from $\mathrm{CHCl}_{3} .{ }^{1} \mathrm{H} \mathrm{NMR}\left(\mathrm{CDCl}_{3}, 500 \mathrm{MHz}, 25^{\circ} \mathrm{C}\right): 9.03-9.01$ (m, $\left.2 \mathrm{H}, \mathrm{NC}_{5} \underline{H}_{5}\right), 7.73-7.70\left(\mathrm{~m}, 1 \mathrm{H}, \mathrm{NC}_{5} \underline{H}_{5}\right), 7.32-$ $7.30\left(\mathrm{~m}, 2 \mathrm{H}, \mathrm{NC}_{5} \underline{H}_{5}\right), 5.32\left(\mathrm{~d}, 1 \mathrm{H},{ }^{2} J_{\mathrm{HH}}=16 \mathrm{~Hz}\right.$, $\mathrm{OCH}_{2}$ of $\left.\mathrm{C}_{9} \underline{H}_{12} \mathrm{~N}_{3} \mathrm{O}\right), 5.02\left(\mathrm{~d}, 1 \mathrm{H},{ }^{2} J_{\mathrm{HH}}=16 \mathrm{~Hz}\right.$, $\mathrm{OCH}_{2}$ of $\mathrm{C}_{9} \underline{H}_{12} \mathrm{~N}_{3} \mathrm{O}$ ), 4.36 (s, 3H, $\underline{\mathrm{C}}_{3}$ ), 3.93-3.89 (m, $1 \mathrm{H}, \mathrm{C}_{6} \underline{H}_{10}$ of $\left.\mathrm{C}_{9} \mathrm{H}_{12} \mathrm{~N}_{3} \mathrm{O}\right), 3.55-3.50\left(\mathrm{~m}, 1 \mathrm{H}, \mathrm{C}_{6} \underline{H}_{10}\right.$ of $\mathrm{C}_{9} \mathrm{H}_{12} \mathrm{~N}_{3} \mathrm{O}$ ), 2.69-2.67 (m, $1 \mathrm{H}, \mathrm{C}_{6} \underline{H}_{10}$ of $\mathrm{C}_{9} \mathrm{H}_{12} \mathrm{~N}_{3} \mathrm{O}$ ), 2.21-2.18 (m, $1 \mathrm{H}, \mathrm{C}_{6} \underline{H}_{10}$ of $\left.\mathrm{C}_{9} \mathrm{H}_{12} \mathrm{~N}_{3} \mathrm{O}\right), 1.93$ (br, $2 \mathrm{H}, \mathrm{C}_{6} \underline{H}_{10}$ of $\left.\mathrm{C}_{9} \mathrm{H}_{12} \mathrm{~N}_{3} \mathrm{O}\right), 1.57-1.41\left(\mathrm{~m}, 4 \mathrm{H}, \mathrm{C}_{6} \underline{H}_{10}\right.$ of $\left.\mathrm{C}_{9} \mathrm{H}_{12} \mathrm{~N}_{3} \mathrm{O}\right) \cdot{ }^{13} \mathrm{C}\left\{{ }^{1} \mathrm{H}\right\}$ NMR $\left(\mathrm{CDCl}_{3}, 125 \mathrm{MHz}\right.$, $\left.25^{\circ} \mathrm{C}\right): \delta 154.0\left(\mathrm{~N}_{\underline{C}} \mathrm{H}_{5}\right), 138.0\left(\mathrm{~N}_{C_{5}} \mathrm{H}_{5}\right), 137.6\left(\underline{C}_{2} \mathrm{~N}_{3}\right.$ of $\left.\mathrm{C}_{9} \mathrm{H}_{12} \mathrm{~N}_{3} \mathrm{O}\right), 129.0\left(\underline{C}_{2} \mathrm{~N}_{3}\right.$ of $\left.\mathrm{C}_{9} \mathrm{H}_{12} \mathrm{~N}_{3} \mathrm{O}\right), 124.5$ $\left(\mathrm{N}_{C_{5}} \mathrm{H}_{5}\right), 76.9\left(\underline{C}_{6} \mathrm{H}_{10}\right.$ of $\left.\mathrm{C}_{9} \mathrm{H}_{12} \mathrm{~N}_{3} \mathrm{O}\right), 64.0\left(\underline{C}_{6} \mathrm{H}_{10}\right.$ of $\left.\mathrm{C}_{9} \overline{\mathrm{H}}_{12} \mathrm{~N}_{3} \mathrm{O}\right), 62.3\left(\mathrm{O}_{\vec{C}} \mathrm{H}_{2}\right.$ of $\left.\mathrm{C}_{9} \mathrm{H}_{12} \mathrm{~N}_{3} \mathrm{O}\right), 43.22\left(\underline{C} \mathrm{H}_{3}\right)$, $30.5\left(\underline{C}_{6} \mathrm{H}_{10}\right.$ of $\left.\mathrm{C}_{9} \mathrm{H}_{12} \mathrm{~N}_{3} \mathrm{O}\right), 29.8\left(\underline{C}_{6} \mathrm{H}_{10}\right.$ of $\left.\mathrm{C}_{9} \mathrm{H}_{12} \mathrm{~N}_{3} \mathrm{O}\right)$, $27.4\left(\underline{C}_{6} \mathrm{H}_{10}\right.$ of $\left.\mathrm{C}_{9} \mathrm{H}_{12} \mathrm{~N}_{3} \mathrm{O}\right), 23.8\left(\underline{C}_{6} \mathrm{H}_{10}\right.$ of $\left.\mathrm{C}_{9} \mathrm{H}_{12} \mathrm{~N}_{3} \mathrm{O}\right)$. IR data $\left(\mathrm{cm}^{-1}\right) \mathrm{KBr}$ pellet: 2923 (m), 2859 (m), 1603 (m), 1525 (w), 1484 (w), 1446 (s), 1370 (w), 1300 (m), 1265 (m), 1207 (w), 1144 (w), 1088 (s), 1066 (m), 1046 (w), $1024(\mathrm{w}), 904(\mathrm{w}), 877(\mathrm{w}), 842(\mathrm{~m}), 761(\mathrm{~m}), 696$ (m), $670(\mathrm{w})$. HRMS (ES): $\mathrm{m} / \mathrm{z}$ 654.8688, $[\mathrm{M}+\mathrm{Na}]^{+}$, Calcd. 654.8659. Anal. Calcd. for $\mathrm{C}_{15} \mathrm{H}_{20} \mathrm{I}_{2} \mathrm{~N}_{4} \mathrm{OPd}$ : C, 28.48; H, 3.19; N, 8.86. Found: C, 29.26; H, 3.18; N, 7.97 . 
2.4 Synthesis of 3-ethyl-5a,6,7,8,9,9a-hexahydro-4Hbenzo[b][1,2,3]triazolo[1,5-d][1,4]oxazinium iodide (2a)

A mixture of $5 \mathrm{a}, 6,7,8,9,9 \mathrm{a}$-hexahydro- $4 H$-benzo[ $b]$ $[1,2,3]$ triazolo[1,5- $d][1,4]$ oxazine $(2.13 \mathrm{~g}, 11.9 \mathrm{mmol})$ and ethyl iodide $(9.30 \mathrm{~g}, 59.6 \mathrm{mmol})$ was refluxed overnight in acetonitrile ( $c a .100 \mathrm{~mL}$ ), after which, the solvent was removed under vacuum. The yellow solid thus obtained was further purified by column chromatography using silica gel as a stationary phase and eluted with methanol/chloroform $(v / v 1: 9)$ to give the product a light yellow solid 2a $(2.67 \mathrm{~g}, 67 \%) .{ }^{1} \mathrm{H}$ NMR $\left(\mathrm{CDCl}_{3}, 500 \mathrm{MHz}, 25^{\circ} \mathrm{C}\right): \delta 9.22\left(\mathrm{~s}, 1 \mathrm{H}, \mathrm{C}_{2} \underline{\mathrm{HN}} \mathrm{N}_{3}\right.$ of $\left.\mathrm{C}_{9} \mathrm{H}_{13} \mathrm{~N}_{3} \mathrm{O}\right), 5.28\left(\mathrm{~d}, 1 \mathrm{H},{ }^{2} J_{\mathrm{HH}}=16 \mathrm{~Hz}, \mathrm{OCH}_{2}\right.$ of $\left.\mathrm{C}_{9} \underline{H}_{13} \mathrm{~N}_{3} \mathrm{O}\right), 5.18\left(\mathrm{~d}, 1 \mathrm{H},{ }^{2} J_{\mathrm{HH}}=16 \mathrm{~Hz}, \mathrm{OCH}_{2}\right.$ of $\left.\mathrm{C}_{9} \underline{H}_{13} \mathrm{~N}_{3} \mathrm{O}\right), 4.82-4.73\left(\mathrm{~m}, 2 \mathrm{H}, \mathrm{C}_{2} \mathrm{CH}_{3}\right), 4.19-4.14$ $\left(\mathrm{m}, 1 \mathrm{H}, \mathrm{C}_{6} \underline{H}_{10}\right.$ of $\left.\mathrm{C}_{9} \mathrm{H}_{13} \mathrm{~N}_{3} \mathrm{O}\right), 3.91\left(\mathrm{dt}, 1 \mathrm{H},{ }^{2} J_{\mathrm{HH}}=10\right.$ $\mathrm{Hz},{ }^{3} J_{\mathrm{HH}}=4 \mathrm{~Hz}, \mathrm{C}_{6} \underline{H}_{10}$ of $\left.\mathrm{C}_{9} \mathrm{H}_{13} \mathrm{~N}_{3} \mathrm{O}\right), 2.75-2.72(\mathrm{~m}$, $1 \mathrm{H}, \mathrm{C}_{6} \underline{H}_{10}$ of $\left.\mathrm{C}_{9} \mathrm{H}_{13} \mathrm{~N}_{3} \mathrm{O}\right), 2.18-2.16\left(\mathrm{~m}, 1 \mathrm{H}, \mathrm{C}_{6} \underline{H}_{10}\right.$ of $\mathrm{C}_{9} \mathrm{H}_{13} \mathrm{~N}_{3} \mathrm{O}$ ), $1.99-1.79$ (m, $3 \mathrm{H}, \mathrm{C}_{6} \underline{H}_{10}$ of $\mathrm{C}_{9} \mathrm{H}_{13} \mathrm{~N}_{3} \mathrm{O}$ ), $1.68\left(\mathrm{t}, 3 \mathrm{H},{ }^{3} J_{\mathrm{HH}}=8 \mathrm{~Hz}, \mathrm{CH}_{2} \underline{\mathrm{CH}}_{3}\right), 1.56-1.47(\mathrm{~m}$, $3 \mathrm{H}, \mathrm{C}_{6} \underline{H}_{10}$ of $\left.\mathrm{C}_{9} \mathrm{H}_{13} \mathrm{~N}_{3} \mathrm{O}\right) .{ }^{13} \mathrm{C}\left\{{ }^{1} \mathrm{H}\right\}$ NMR $\left(\mathrm{CDCl}_{3}, 125\right.$ $\left.\mathrm{MHz}, 2^{\circ} \mathrm{C}\right): \delta 137.3\left(\underline{C}_{2} \mathrm{HN}_{3}\right.$ of $\left.\mathrm{C}_{9} \mathrm{H}_{13} \mathrm{~N}_{3} \mathrm{O}\right), 127.3$ $\left(\underline{C}_{2} \mathrm{HN}_{3}\right.$ of $\left.\mathrm{C}_{9} \mathrm{H}_{13} \mathrm{~N}_{3} \mathrm{O}\right), 77.0\left(\underline{C}_{6} \mathrm{H}_{10}\right.$ of $\left.\mathrm{C}_{9} \mathrm{H}_{13} \mathrm{~N}_{3} \mathrm{O}\right)$, $63.7\left(\underline{C}_{6} \mathrm{H}_{10}\right.$ of $\left.\mathrm{C}_{9} \mathrm{H}_{13} \mathrm{~N}_{3} \mathrm{O}\right), 61.9\left(\mathrm{O}^{C} \mathrm{H}_{2}\right.$ of $\left.\mathrm{C}_{9} \mathrm{H}_{13} \mathrm{~N}_{3} \mathrm{O}\right)$, $50.1\left(\underline{C} \mathrm{H}_{2} \mathrm{CH}_{3}\right), 30.0 \quad\left(\underline{C}_{6} \mathrm{H}_{10}\right.$ of $\left.\mathrm{C}_{9} \mathrm{H}_{13} \mathrm{~N}_{3} \mathrm{O}\right), 27.2$ $\left(\underline{C}_{6} \mathrm{H}_{10}\right.$ of $\left.\mathrm{C}_{9} \mathrm{H}_{13} \mathrm{~N}_{3} \mathrm{O}\right), 23.5\left(\underline{C}_{6} \mathrm{H}_{10}\right.$ of $\left.\mathrm{C}_{9} \mathrm{H}_{13} \mathrm{~N}_{3} \mathrm{O}\right), 23.2$ $\left(\underline{C}_{6} \mathrm{H}_{10}\right.$ of $\left.\mathrm{C}_{9} \mathrm{H}_{13} \mathrm{~N}_{3} \mathrm{O}\right), 14.8\left(\mathrm{CH}_{2} \underline{C H}_{3}\right)$. IR data $\left(\mathrm{cm}^{-1}\right)$ KBr pellet: 3155 (w), 3118 (w), 2975(w), 2947 (s), 2936 (s), 2863 (m), 1629 (w), 1572 (w), 1450 (m), 1383 (w), $1338(\mathrm{~m}), 1299(\mathrm{w}), 1245(\mathrm{w}), 1160(\mathrm{~m}), 1146$ (m), 1136 (m), 1093 (s), 1082 (s), 1028 (m), 940 (w), $874(\mathrm{w}), 846(\mathrm{w}), 817(\mathrm{~m}), 786(\mathrm{w}), 751(\mathrm{w}), 656(\mathrm{w})$. HRMS (ES): $(\mathrm{M})^{+}, \mathrm{m} / z$ 208.1445, Calcd. 208.1444. Anal. Calcd. for $\mathrm{C}_{11} \mathrm{H}_{18} \mathrm{IN}_{3} \mathrm{O}: \mathrm{C}, 39.42 ; \mathrm{H}, 5.41 ; \mathrm{N}$, 12.54. Found: C, 39.22; H, 5.02; N, 12.45 .

2.5 Synthesis of trans\{ 3-ethyl-5a,6,7,8,9,9ahexahydro-4H-benzo[b][1,2,3]triazolo [1,5-d][1,4] oxazin-4-ylidene\} $\mathrm{PdI}_{2}$ (pyridine) (2b)

A mixture of 3-ethyl-5a,6,7,8,9,9a-hexahydro-4H-benzo $[b][1,2,3]$ triazolo[ $[1,5-d][1,4]$ oxazinium iodide $(0.500$ $\mathrm{g}, 1.49 \mathrm{mmol}), \mathrm{PdCl}_{2}(0.264 \mathrm{~g}, 1.49 \mathrm{mmol}), \mathrm{K}_{2} \mathrm{CO}_{3}$ (1.64 g, $11.9 \mathrm{mmol})$ and $\mathrm{NaI}(1.11 \mathrm{~g}, 7.46 \mathrm{mmol})$ was refluxed in pyridine $(c a .5 \mathrm{~mL})$ for 16 hours. The reaction mixture was then cooled to room temperature, diluted with $\mathrm{CHCl}_{3}$ (ca. $100 \mathrm{~mL}$ ) and subsequently washed with saturated aqueous $\mathrm{CuSO}_{4}$ solution $(\mathrm{ca} .3 \times$ $50 \mathrm{~mL}$ ). The organic layer was separated and dried over anhydrous $\mathrm{Na}_{2} \mathrm{SO}_{4}$ and filtered. The filtrate was concentrated under vacuum to give a sticky, brown residue.
The residue thus obtained was further purified by column chromatography using silica gel as a stationary phase and eluted with methanol/chloroform ( $v / v$ 1:9) mixture to give the product as a yellow solid $\mathbf{2 b}(0.220$ $\mathrm{g}, 23 \%$ ). The product was crystallized from $\mathrm{CH}_{3} \mathrm{CN}$. ${ }^{1} \mathrm{H} \mathrm{NMR}\left(\mathrm{CDCl}_{3}, 500 \mathrm{MHz}, 25^{\circ} \mathrm{C}\right): 9.02-9.01(\mathrm{~m}, 2 \mathrm{H}$, $\left.\mathrm{NC}_{5} \underline{H}_{5}\right), 7.73-7.70\left(\mathrm{~m}, 2 \mathrm{H}, \mathrm{NC}_{5} \underline{H}_{5}\right), 7.32-7.29(\mathrm{~m}$, $\left.1 \mathrm{H}, \mathrm{NC}_{5} \underline{H}_{5}\right), \delta 5.33\left(\mathrm{~d}, 1 \mathrm{H},{ }^{2} J_{\mathrm{HH}}=16 \mathrm{~Hz}, \mathrm{OCH}_{2}\right.$ of $\left.\mathrm{C}_{9} \underline{H}_{12} \mathrm{~N}_{3} \mathrm{O}\right), 5.02\left(\mathrm{~d}, 1 \mathrm{H},{ }^{2} J_{\mathrm{HH}}=16 \mathrm{~Hz}, \mathrm{OCH}_{2}\right.$ of $\mathrm{C}_{9} \underline{H}_{12} \mathrm{~N}_{3} \mathrm{O}$ ), $4.87-4.76\left(\mathrm{~m}, 2 \mathrm{H}, \underline{\mathrm{C}}_{2} \mathrm{CH}_{3}\right), 3.95-3.90$ (m, $1 \mathrm{H}, \mathrm{C}_{6} \underline{H}_{10}$ of $\left.\mathrm{C}_{9} \mathrm{H}_{12} \mathrm{~N}_{3} \mathrm{O}\right), 3.56-3.53\left(\mathrm{~m}, 1 \mathrm{H}, \mathrm{C}_{6} \underline{H}_{10}\right.$ of $\mathrm{C}_{9} \mathrm{H}_{12} \mathrm{~N}_{3} \mathrm{O}$ ), 2.71-2.68 (m, $1 \mathrm{H}, \mathrm{C}_{6} \underline{\mathrm{H}}_{10}$ of $\mathrm{C}_{9} \mathrm{H}_{12} \mathrm{~N}_{3} \mathrm{O}$ ), 2.21-2.19 (m, $1 \mathrm{H}, \mathrm{C}_{6} \underline{H}_{10}$ of $\mathrm{C}_{9} \mathrm{H}_{12} \mathrm{~N}_{3} \mathrm{O}$ ), 1.96-1.91 (m, $2 \mathrm{H}, \mathrm{C}_{6} \underline{H}_{10}$ of $\left.\mathrm{C}_{9} \mathrm{H}_{12} \mathrm{~N}_{3} \mathrm{O}\right), 1.74\left(\mathrm{t}, 3 \mathrm{H},{ }^{3} J_{\mathrm{HH}}=8 \mathrm{~Hz}\right.$, $\left.\mathrm{CH}_{2} \underline{\mathrm{C}}_{3}\right)$, 1.61-1.41 (m, $4 \mathrm{H}, \mathrm{C}_{6} \underline{H}_{10}$ of $\left.\mathrm{C}_{9} \mathrm{H}_{12} \mathrm{~N}_{3} \mathrm{O}\right)$. ${ }^{13} \mathrm{C}\left\{{ }^{1} \mathrm{H}\right\}$ NMR $\left(\mathrm{CDCl}_{3}, 125 \mathrm{MHz}, 25^{\circ} \mathrm{C}\right): \delta 153.8$ $\left(\mathrm{N}_{C_{5}} \mathrm{H}_{5}\right), 137.6\left(\mathrm{~N}_{C_{5}} \mathrm{H}_{5}\right), 137.4\left(\underline{C}_{2} \mathrm{~N}_{3}\right.$ of $\left.\mathrm{C}_{9} \mathrm{H}_{12} \mathrm{~N}_{3} \mathrm{O}\right)$, $127.4\left(\underline{C}_{2} \mathrm{~N}_{3}\right.$ of $\left.\mathrm{C}_{9} \mathrm{H}_{12} \mathrm{~N}_{3} \mathrm{O}\right), 124.3\left(\mathrm{~N}_{5} \mathrm{H}_{5}\right), 76.8$ $\left(\underline{C}_{6} \mathrm{H}_{10}\right.$ of $\left.\mathrm{C}_{9} \mathrm{H}_{12} \mathrm{~N}_{3} \mathrm{O}\right), 64.0\left(\underline{C}_{6} \mathrm{H}_{10}\right.$ of $\left.\mathrm{C}_{9} \mathrm{H}_{12} \mathrm{~N}_{3} \mathrm{O}\right), 62.2$ $\left(\mathrm{O}^{C} \mathrm{H}_{2}\right.$ of $\left.\mathrm{C}_{9} \mathrm{H}_{12} \mathrm{~N}_{3} \mathrm{O}\right), 51.3\left(\underline{C H}_{2}\right), 30.3\left(\underline{C}_{6} \mathrm{H}_{10}\right.$ of $\left.\mathrm{C}_{9} \overline{\mathrm{H}}_{12} \mathrm{~N}_{3} \mathrm{O}\right), 27.2\left(\underline{C}_{6} \mathrm{H}_{10}\right.$ of $\left.\mathrm{C}_{9} \mathrm{H}_{12} \mathrm{~N}_{3} \mathrm{O}\right), 23.7\left(\underline{C}_{6} \mathrm{H}_{10}\right.$ of $\left.\mathrm{C}_{9} \mathrm{H}_{12} \mathrm{~N}_{3} \mathrm{O}\right), 23.6\left(\underline{C}_{6} \mathrm{H}_{10}\right.$ of $\left.\mathrm{C}_{9} \mathrm{H}_{12} \mathrm{~N}_{3} \mathrm{O}\right), 14.7\left(\underline{C} \mathrm{H}_{3}\right)$. IR data $\left(\mathrm{cm}^{-1}\right) \mathrm{KBr}$ pellet: 2937 (m), 2861 (m), 1603 (m), $1483(\mathrm{w}), 1445(\mathrm{~s}), 1370(\mathrm{w}), 1299$ (m), 1238 (w), 1146 (w), 1090 (s), 1066 (m), 1026 (m), 938 (w), $877(\mathrm{w}), 831(\mathrm{w}), 757$ (m), $691(\mathrm{~m})$. HRMS (ES): $\mathrm{m} / \mathrm{z}$ 668.8818, $[\mathrm{M}+\mathrm{Na}]^{+}$, Calcd. 668.8816. Anal. Calcd. for $\mathrm{C}_{16} \mathrm{H}_{22} \mathrm{I}_{2} \mathrm{~N}_{4} \mathrm{OPd}$ : C, 29.72; H, 3.43; N, 8.66. Found: C, 29.94; H, 3.04; N, 8.42.

\section{Results and Discussions}

A new type of the tricyclic triazolooxazine derived $\mathrm{N}$ heterocyclic carbene namely, 3-(R)-5a,6,7,8,9,9a-hexahydro-4 $H$-benzo[ $b][1,2,3]$ triazolo[1,5- $d][1,4]$ oxazin-4 -ylidene $[\mathrm{R}=\mathrm{Me}, \mathrm{Et}]$, was developed to assess its potential as a new ligand in the backdrop of their largely successful imidazole derived counterparts in homogeneous catalysis. The tricyclic triazolooxazine derived $\mathrm{N}$-heterocyclic carbene precursors (1-2)a, were

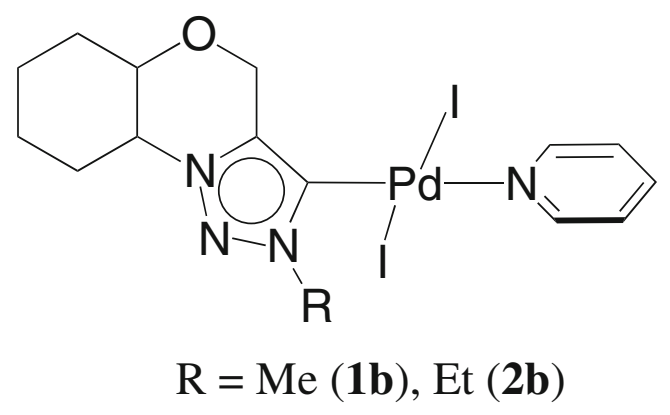

Figure 1. Pd complexes of the tricyclic triazolooxazine derived N-heterocyclic carbene (NHC) ligands. 
obtained from the reaction of 5a,6,7,8,9,9a-hexahydro$4 H$-benzo $[b][1,2,3]$ triazolo[ $[1,5-d][1,4]$ oxazine with the methyl and ethyl iodides in refluxing $\mathrm{CH}_{3} \mathrm{CN}$ in 67-84 \% yield. The formation of the carbene precursors (1-2)a were evident from the presence of the pro-carbene centre proton resonance corresponding to the 4-position of the tricyclic triazolooxazine ring at 9.24 ppm (1a) and 9.22 ppm (2a) in the ${ }^{1} \mathrm{H}$ NMR spectrum and the pro-carbene centre carbon resonance in the $127.9 \mathrm{ppm}(\mathbf{1 a})$ and $127.2 \mathrm{ppm}(\mathbf{2 a})$ in the ${ }^{13} \mathrm{C} \mathrm{NMR}$ spectrum. The HRMS spectrum of the 3-(R)-tricyclic triazolooxazinium iodide salts $(\mathbf{1}-\mathbf{2}) \mathbf{a}$ exhibited $\mathrm{m} / \mathrm{z}$ peaks at 194.1288 (1a) and 208.1444 (2a) consistent with the respective calculated values of $194.1293(\mathrm{~m} / \mathrm{z})$ and $208.1450(\mathrm{~m} / \mathrm{z})$.

The stabilization of the new tricyclic triazolooxazine derived $\mathrm{N}$-heterocyclic carbene was achieved in its palladium complexes, $(\mathbf{1}-\mathbf{2}) \mathbf{b}$ that were obtained by treating 3-(R)-tricyclic triazolooxazinium iodide salts (1-2)a with $\mathrm{PdCl}_{2}$ in presence of $\mathrm{K}_{2} \mathrm{CO}_{3}$ in refluxing pyridine in $23-25 \%$ yield. Consistent with the presence of a metal bound carbene moiety, the palladium complexes $(\mathbf{1}-\mathbf{2}) \mathbf{b}$, exhibited an expected $\mathrm{Pd}-\mathrm{C}_{\text {carbene }}$ resonance at the $129.0 \mathrm{ppm}(\mathbf{1 b})$ and $127.4 \mathrm{ppm}(\mathbf{2 b})$ in the ${ }^{13} \mathrm{C}$ NMR spectrum and an absence of a peak in the 9.22-9.24 ppm region of the ${ }^{1} \mathrm{H}$ NMR spectrum, where the pro-carbene centre proton resonance of the 4-position of the tricyclic triazolooxazine ring of the starting material (1-2)a appeared.

The final confirmation, however, came from the molecular structure determination of the palladium (1-2)b complexes, that showed that the tricyclic triazolooxazine derived $\mathrm{N}$-heterocyclic carbene moiety was indeed bound to a square planar palladium centre trans to a pyridine moiety while the remaining two sites around the metal centre were occupied by two iodide atoms (figures 1-3, table 1 and scheme1). Consistent with a square planar geometry, all of the four angles at palladium namely, the $\angle \mathrm{C}_{\text {carbene }}-\mathrm{Pd}-\mathrm{I}$ and the $\angle \mathrm{I}-\mathrm{Pd}-\mathrm{N}_{\text {pyridine }}$, and their respective complementary angles are close to 90 degrees. The $\mathrm{Pd}-\mathrm{I}$ distances were observed to be of 2.6187(17) $\AA$ and 2.5904(17) $\AA$ in $\mathbf{1 b}$ and of 2.6123(10) $\AA$ and 2.6031(10) $\AA$ in $\mathbf{2 b}$.

Of foremost importance, is the $\mathrm{Pd}-\mathrm{C}_{\text {carbene }}$ distance

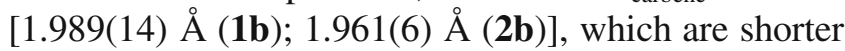
than the sum of the individual covalent radii of Pd and $\mathrm{C}(2.055 \AA)^{22}$ but fall well within the range observed in other related representative complexes like the triazole derived trans-[1-ethyl-3-methyl-4-phenyltriazol-5-ylidene $] \mathrm{PdCl}_{2}$ (3-chloropyridine) [1.9601(16) $\left.\AA\right],{ }^{23}$ trans[1,4-di-n-butyl-3-methyltriazol-5-ylidene] $\mathrm{PdCl}_{2}$ (3-chloropyridine) $[1.9650(13) \AA]$, ${ }^{23}$ trans-[1-mesityl-3-methyl-4-phenyltriazol-5-ylidene $] \mathrm{PdCl}_{2}$ (3-chloropyridine) [1.957(3) $\AA$ ] ${ }^{23}$ trans-[1,4-bis(2,6-diisopropylphenyl)3-methyltriazol-5-ylidene] $\mathrm{PdCl}_{2}$ (3-chloropyridine) [1.965(2) ̊],${ }^{24}[$ trans-[4-benzyl-1-i-propyl-1,2,4-triazol5-ylidene] $\mathrm{PdBr}_{2}$ (pyridine) [1.950(9) $\left.\AA\right]^{18}$ and trans-[4benzyl-1-( $t$-butylaminocarbonylmethyl)-1,2,4-triazol5-ylidene $] \mathrm{PdBr}_{2}$ (pyridine) [1.946(3) $\left.\AA\right]^{18}$ complexes and the imidazole derived trans-[1-(benzyl)-3- $(N-$ $t$-butylacetamido)imidazol-2-ylidene] $\mathrm{PdCl}_{2}$ (pyridine) [1.957(3) $\AA$ ] , ${ }^{25}$ and [trans-[1-(2-hydroxy-cyclohexyl)-

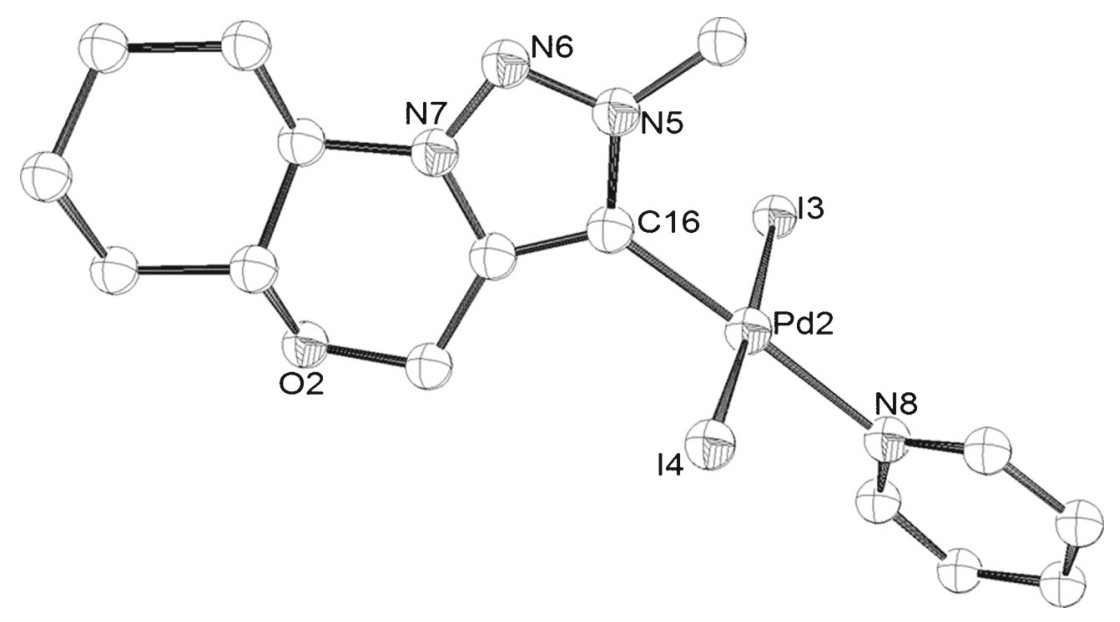

Figure 2. ORTEP of $\mathbf{1 b}$ with thermal ellipsoids are shown at the 50\% probability level. Selected bond lengths $(\AA)$ and angles $\left({ }^{\circ}\right)$ : $\operatorname{Pd}(2)-C(16)$ 1.989(14), $\quad \mathrm{Pd}(2)-\mathrm{N}(8)$ 2.090(11), $\mathrm{Pd}(2)-\mathrm{I}(3)$ 2.6187(17), $\mathrm{Pd}(2)-\mathrm{I}(4)$ 2.5904(17), $\quad \mathrm{C}(16)-\mathrm{Pd}(2)-\mathrm{N}(8) \quad 177.9(6), \quad \mathrm{C}(16)-\mathrm{Pd}(2)-\mathrm{I}(3) \quad 89.6(4)$, $\mathrm{N}(8)-\mathrm{Pd}(2)-\mathrm{I}(3) \quad 92.3(3), \quad \mathrm{C}(16)-\mathrm{Pd}(2)-\mathrm{I}(4) \quad 86.1(4) ， \quad \mathrm{~N}(8)-\mathrm{Pd}(2)-\mathrm{I}(4)$ $92.0(3), \mathrm{I}(4)-\mathrm{Pd}(2)-\mathrm{I}(3) 175.15(6)$. 


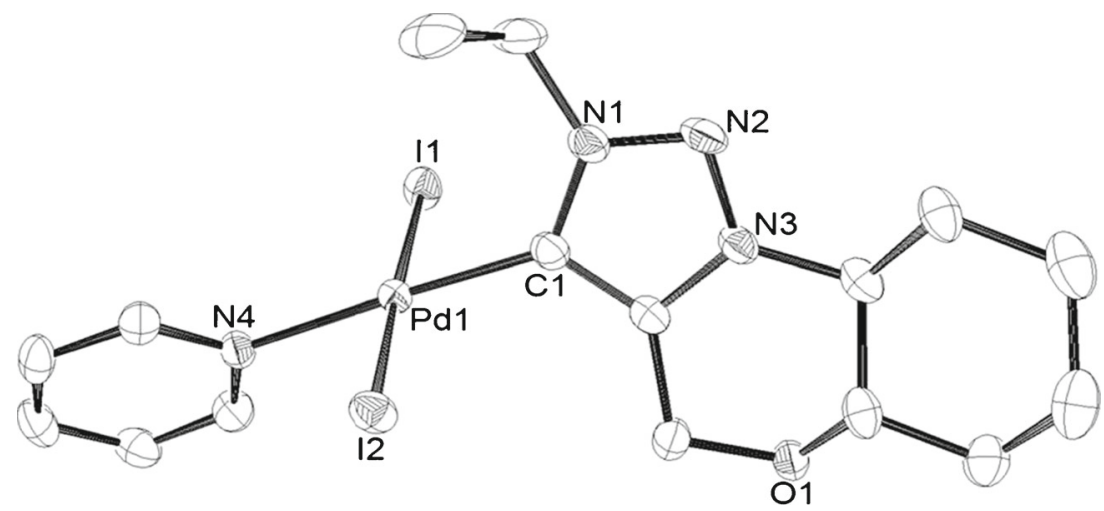

Figure 3. ORTEP of $\mathbf{2 b}$ with thermal ellipsoids are shown at the $50 \%$ probability level. Selected bond lengths $(\AA)$ and angles $\left(^{\circ}\right)$ : $\mathrm{Pd}(1)-\mathrm{C}(1)$ 1.961(6), $\mathrm{Pd}(1)-\mathrm{N}(4)$ 2.096(5), $\mathrm{Pd}(1)-\mathrm{I}(1)$ 2.6123(10), $\mathrm{Pd}(1)-\mathrm{I}(2)$ 2.6031(10), $\mathrm{C}(1)-\mathrm{Pd}(1)-\mathrm{N}(4)$ 177.7(2), C(1)-Pd(1)-I(1) 88.58(16), N(4)-Pd(1)-I(1) 92.37(12), $\quad \mathrm{C}(1)-\mathrm{Pd}(1)-\mathrm{I}(2) \quad 88.38(16), \quad \mathrm{N}(4)-\mathrm{Pd}(1)-\mathrm{I}(2) \quad 90.17(12)$, $\mathrm{I}(2)-\mathrm{Pd}(1)-\mathrm{I}(1) 176.71(2)$.

3-(benzyl)imidazol-2-ylidene] $\mathrm{PdCl}_{2}$ (pyridine) [1.967(4) $\AA],{ }^{25}$ complexes.

The $\mathrm{Pd}-\mathrm{N}_{\text {pyridine }}$ distance $[2.090(11) \quad(\AA) \quad$ (1b); 2.096(5) ( $\AA$ ) (2b)] are longer than the sum of the individual covalent radii of Pd and $\mathrm{N}(1.983 \AA)^{22}$ but are comparable to the other related complexes like the triazole derived trans-[1-ethyl-3-methyl-4-phenyltriazol5-ylidene $] \mathrm{PdCl}_{2}$ (3-chloropyridine) $[2.1105(13) \quad \AA],{ }^{23}$ trans-[1,4-di-n-butyl-3-methyltriazol-5-ylidene] $\mathrm{PdCl}_{2}$ (3-chloropyridine) [2.1192(11) $\AA]$, ${ }^{23}$ trans-[1-mesityl3-methyl-4-phenyltriazol-5-ylidene] $\mathrm{PdCl}_{2}$ (3-chloropyridine) $[2.129(3) \AA],{ }^{23}$ trans-[1,4-bis(2,6-diisopropylphenyl)-3-methyltriazol-5-ylidene] $\mathrm{PdCl}_{2}$ (3-chloropyridine) $[2.089(2) \AA],{ }^{24}$ trans-[4-benzyl-1-i-propyl-1,2, 4-triazol-5-ylidene $] \mathrm{PdBr}_{2}$ (pyridine) $[2.092(8) \AA]^{18}$ and trans-[4-benzyl-1-( $t$-butylaminocarbonylmethyl)-1,2,4triazol-5-ylidene $] \mathrm{PdBr}_{2}$ (pyridine) $[2.100(3) \AA]^{18}$ complexes and the imidazole derived trans-[1-(benzyl)-3-

Table 1. X-ray crystallographic data for $\mathbf{1 b}$ and $\mathbf{2 b}$.

\begin{tabular}{lcc}
\hline Compound & $\mathbf{1 b}$ & $\mathbf{2 b}$ \\
\hline Lattice & Triclinic & Monoclinic \\
Formula & $\mathrm{C}_{15} \mathrm{H}_{20} \mathrm{I}_{2} \mathrm{~N}_{4} \mathrm{OPd}$ & $\mathrm{C}_{16} \mathrm{H}_{22} \mathrm{I}_{2} \mathrm{~N}_{4} \mathrm{OPd}$ \\
Formula weight & 632.55 & 646.58 \\
Space group & $P-1$ & $P 21 / c$ \\
$\mathrm{a} / \AA$ & $10.087(5)$ & $10.265(5)$ \\
$\mathrm{b} / \AA$ & $12.898(7)$ & $13.121(6)$ \\
$\mathrm{c} / \AA$ & $15.835(7)$ & $15.757(8)$ \\
$\alpha /{ }^{\circ}$ & $87.335(16)$ & 90 \\
$\beta /{ }^{\circ}$ & $74.701(14)$ & $104.239(8)$ \\
$\gamma /{ }^{\circ}$ & $83.549(16)$ & 90 \\
$\mathrm{~V} / \AA^{3}$ & $1974.3(17)$ & $2057.1(17)$ \\
$\mathrm{Z}$ & 4 & 4 \\
Temperature $(\mathrm{K})$ & $100(2)$ & $100(2)$ \\
Radiation $(\lambda, \AA)$ & 0.7107 & 0.7107 \\
$\rho\left(\right.$ calcd.), $\mathrm{g} \mathrm{c}^{-3}$ & 2.128 & 2.088 \\
$\mu($ Mo $\alpha), \mathrm{m}^{-1}$ & 4.076 & 3.914 \\
$\theta$ max, deg. & 29.21 & 25.00 \\
No. of data & 10547 & 3608 \\
No. of parameters & 420 & 217 \\
$\mathrm{R}_{1}$ & 0.0878 & 0.0384 \\
$w \mathrm{R}_{2}$ & 0.2128 & 0.0720 \\
GOF & 1.116 & 1.161 \\
\hline
\end{tabular}




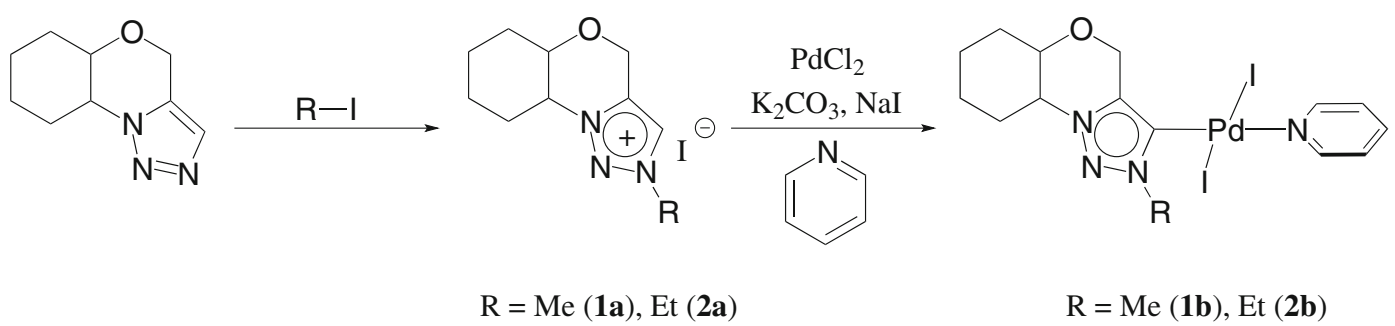

Scheme 1. Synthesis of Pd-NHC complexes (1-2)b.

( $N$ - $t$-butylacetamido)imidazol-2-ylidene $] \mathrm{PdCl}_{2}$ (pyridine) [2.089(3) $\AA],{ }^{25}$ and trans-[1-(2-hydroxy-cyclohexyl)-3(benzyl)imidazol-2-ylidene] $\mathrm{PdCl}_{2}$ (pyridine) [2.096(3) $\AA]^{25}$ complexes.

Overall, though the tricyclic triazolooxazine derived $\mathrm{N}$-heterocyclic carbene ligand exhibited analogous binding orientation to palladium similar to the other commonly observed imidazole and traizole derived N- heterocyclic carbene ligands in the ( $\mathrm{NHC} \mathrm{PdI}_{2}$ (pyridine) type complexes, their steric and electronic influences on the metal remains to be uncovered and would be the subject of future publications from the group.

\section{Conclusion}

A new type of tricyclic triazolooxazine derived $\mathrm{N}$-heterocyclic carbene ligand precursors namely, 3-(R)-5a,6,7,8,9,9a-hexahydro-4H-benzo[b] [1,2,3]triazolo[1,5-d][1,4]oxazinium iodide, (1-2)a, was conveniently synthesized by the alkylation reaction of a tricyclic triazolooxazine framework. The new tricyclic triazolooxazine derived $\mathrm{N}$-heterocyclic carbene moiety was stabilized in its palladium complexes, $(\mathbf{1}-\mathbf{2}) \mathbf{b}$, which were obtained upon metallation of the tricyclic triazolooxazinium iodide salts, $(\mathbf{1 - 2}) \mathbf{a}$, with $\mathrm{PdCl}_{2}$ in presence of $\mathrm{K}_{2} \mathrm{CO}_{3}$ in pyridine.

\section{Supplementary Information}

CCDC-983594 (for 1b), CCDC-978994 (for 2b) contain the supplementary crystallographic data for this paper. These data can be obtained free of charge from the Cambridge Crystallographic Data center via www. ccdc.cam.ac.uk/data_request/cif.

\section{Acknowledgements}

We thank Department of Science and Technology (Grant No: SR/S1/IC-50/2011), New Delhi, for financial support of this research. We thank Professor R. Murugavel for the use of his Single Crystal X-ray Diffraction Facility established through a DAE-SRC
Outstanding Investigator Award along with the Single Crystal X-ray Diffraction Facility, Department of Chemistry IIT Bombay, India, for the crystallographic characterization data. MKG thanks CSIR, New Delhi for research fellowship.

\section{References}

1. (a) Canac Y, Soleilhavoup M, Conejero S and Bertrand G 2004 J. Organomet. Chem. 689 3857; (b) Bourissou D, Guerret O, Gabbaï F P and Bertrand G 2000 Chem. Rev. 10039

2. Schuster O, Yang L, Raubenheimer H G and Albrecht M 2009 Chem. Rev. 1093445

3. (a) Boeda F and Nolan S P 2008 Ann. Rep. Prog. Chem. Sect. B 104 184; (b) Hahn F E and Jahnke M C 2008 Angew. Chem. Int. Ed. 473122

4. Han Y and Huynh H V 2011 Dalton Trans. 402141

5. (a) Verlinden K and Ganter C 2014 J. Organomet. Chem. 750 23; (b) Dunsford J J, Tromp D S, Cavell K J, Elsevier C J and Kariuki B M 2013 Dalton Trans. 42 7318; (c) Kolychev E L, Asachenko A F, Dzhevakov P B, Bush A A, Shuntikov V V, Khrustalevc V N and Nechaev M S 2013 Dalton Trans. 426859

6. Scarborough C C, Popp B V, Guzei I A and Stahl S S 2005 J. Organomet. Chem. 6906143

7. Lu W Y, Cavell K J, Wixey J S and Kariuki B 2011 Organometallics 305649

8. (a) Boyarskiya V P, Luzyanina K V and Kukushkina V Y 2012 Coord. Chem. Rev. 256 2029; (b) Vignolle J, Cattoën X and Bourissou D 2009 Chem. Rev. 1093333

9. (a) Hashmi A S K, Riedel D, Rudolph M, Rominger F and Oeser T 2012 Chem. Eur. J. 18 3827; (b) Arnold P L and Pearson S 2007 Coord. Chem. Rev. 251596

10. Crabtree R H 2013 Coord. Chem. Rev. 257755

11. (a) Chen X Y and Ye S 2013 Synlett 24 1614; (b) Wanga F, Liua L J, Wanga W, Li S and Shia M 2012 Coord. Chem. Rev. 256 804; (c) Douthwaite R E 2007 Coord. Chem. Rev. 251 702; (d) Gadea L H and Laponnaz S B 2007 Coord. Chem. Rev. 251 718; (e) Cèsar V, Laponnaz S B and Gade L H 2004 Chem. Soc. Rev. 33619

12. McGuinness D 2009 Dalton Trans. 6915

13. (a) Bugaut X and Glorius F 2012 Chem. Soc. Rev. 41 3511; (b) Enders D, Niemeier O and Henseler A 2007 Chem. Rev. 1075606

14. (a) Valente C, Pompeo M, Sayah M and Organ M G 2014 Org. Process Res. Dev. 18 180; (b) Bèzier D, Sortais J B and Darcel C 2013 Adv. Synth. Catal. 355 
193; (c) Hamadd F B, Suna T, Xiaoa S and Verpoorta F 2013 Coord. Chem. Rev. 257 2274; (d) Budagumpi S, Haque R A, Endud S, Rehman G U and Salman A W 2013 Eur. J. Inorg. Chem. 4367; (d) Budagumpi S and Endud S 2013 Organometallics 32 1537; (e) Valente C, alimsiz S, Hoi K H, Mallik D, Sayah M and Organ M G 2012 Angew. Chem. Int. Ed. 513314

15. Izquierdo J, Hutson G E, Cohen D T and Scheidt K A 2012 Angew. Chem. Int. Ed. 5111686

16. (a) Kumar A and Ghosh P 2012 Eur. J. Inorg. Chem. 3955; (b) Ghosh P 2011 J. Indian I. Sci. 91 521; (c) John A and Ghosh P 2010 Dalton Trans. 397183

17. (a) Kumar S, Narayanan A, Rao M N, Shaikh M M and Ghosh P 2012J. Organomet. Chem. 696 4159; (b) Samantaray M K, Dash C, Shaikh M M, Pang K, Butcher R J and Ghosh P 2011 Inorg. Chem. 50 1840; (c) Kumar S, Narayanan A, Rao M N, Shaikh M M and Ghosh P 2011 J. Chem. Sci. 123 791; (d) Ray S, Shaikh M M and Ghosh P 2009 Eur. J. Inorg. Chem. 1932; (e) Samantaray M K, Shaikh M M and Ghosh P 2009 J. Organomet. Chem. 694 3477; (f) Ray L, Barman S, Shaikh M M and Ghosh P 2008 Chem. Eur. J. 14 6646; (g) Samantaray M K, Pang K, Shaikh M M and Ghosh P 2008 Inorg. Chem. 47 4153; (h) Ray L, Shaikh M M and Ghosh P 2007 Organometallics 26 958; (i) Ray S, Mohan R, Singh J K, Samantaray M K, Shaikh M M, Panda D and Ghosh P 2007 J. Am. Chem. Soc. 129
15042; (j) Samantaray M K, Katiyar V, Roy D, Pang K, Nanavati H, Stephen R, Sunoj R B and Ghosh P 2006 Eur. J. Inorg. Chem. 2975; (k) Ray L, Katiyar V, Raihan M J, Nanavati H, Shaikh M M and Ghosh P 2006 Eur. J. Inorg. Chem. 3724

18. Dash C, Shaikh M M and Ghosh P 2009 Eur. J. Inorg. Chem. 1608

19. Kumar A, Katari M and Ghosh P 2013 Polyhedron 52 524

20. (a) John A, Modak S, Madasu M, Katari M and Ghosh P 2013 Polyhedron 64 20; (b) Dash C, Shaikh M M and Ghosh P 2011 J. Chem. Sci. 123 97; (c) John A and Ghosh P 2010 Dalton Trans. 39 7183; (d) John A, Shaikh M M and Ghosh P 2010 Inorg. Chim. Acta 363 3113

21. Li R, Jansen D J and Datta A 2009 Org. Biomol. Chem. 71921

22. Pauling L In The Nature of the Chemical Bond 1960 ( $3^{\text {rd }}$ ed.) (NY: Cornell University Press) pp. 224-228, 256-258

23. Gonzalez D C, Gniewek A, Szulmanowicz M, Bunz H M, Trzeciak A M and Albrecht M 2012 Chem. Eur. J. 186055

24. Huang J, Hong J T and Hong S H 2012 Eur. J. Org. Chem. 6630

25. Ray L, Shaikh M M and Ghosh P 2007 Dalton Trans. 4546 